\title{
Sustainable Technology in Developed Countries: Waste Municipal Management
}

\author{
Carol Emilly Hoareau ${ }^{*}$, Noraziah Ahmad ${ }^{2}$, Maria Nuid $^{3}$, Rubiyatno ${ }^{4}$, Dao Nguyen \\ Khoi $^{5,6}$, Risky Ayu Kristanti ${ }^{7}$ \\ ${ }^{1}$ Department of Civil Construction Engineering, Faculty of Engineering Science, Curtin University, CDT 250, Miri, 98009 , \\ Sarawak, Malaysia \\ ${ }^{2}$ Faculty of Civil Engineering Technology, Universiti Malaysia Pahang, Lebuhraya Tun Razak, 26300 Gambang, Pahang, \\ Malaysia \\ ${ }^{3}$ School of Civil Engineering, Faculty of Engineering, Universiti Teknologi Malaysia, 81310 UTM Johor, Malaysia \\ ${ }^{4}$ Integrated Graduate School of Medicine, Engineering, and Agricultural Sciences, University of Yamanashi, Japan. \\ ${ }^{5}$ Faculty of Environment, University of Science, 227 Nguyen Van Cu Street, Dist. 5, Ho Chi Minh City, Vietnam \\ ${ }^{6}$ Vietnam National University Ho Chi Minh City, Linh Trung Ward, Thu Duc Dist., Ho Chi Minh City, Vietnam \\ ${ }^{7}$ Research Center for Oceanography, National Research and Innovation Agency, Jakarta, 14430, Indonesia \\ *Correspondence: carol.hoareau06@gmail.com
}

SUBMITTED: 26 November 2021; REVISED: 19 December 2021; ACCEPTED: 20 December 2021

\begin{abstract}
As more studies were conducted and global events unfold, a greater emphasis is being placed on the importance of preserving the Earth's natural resources and cycles before we face a catastrophic climate crisis. Thus, developed countries are constantly adapting their policies and legislation to promote green development for the sake of sustainable development, which benefits both the environment and the socioeconomic segment. As populations grow and living standards improve, more waste is generated. Appropriate municipal waste management is necessary to avoid harm to the environment, wildlife, and human health. Sustainable municipal solid waste management is even included in the United Nations' (UN) Sustainable Development Goals, which aim to improve the world's environment and economy. The European Union (EU) member states' waste management systems can be considered exemplary. In some countries, landfills have been prohibited, promoting the use of more sustainable technologies such as organic waste incineration, recycling, and composting. However, a divide exists between member countries, with some lagging behind in terms of waste management strategies. Thus, this paper examined the current state of municipal waste in EU member states, followed by a review of the various disposal technologies implemented. The difficulties and environmental concerns that must be overcome are discussed, as are the recommendations and possible future directions.
\end{abstract}

KEYWORDS: Municipal waste; waste treatment technology; sustainability; waste management 


\section{Introduction}

As global environmental issues such as rising temperatures and climate change receive increased attention, both developed and developing countries are increasingly directing their resources toward sustainable development and growth. Sustainability is a broad term that encompasses a variety of social, economic, and environmental factors. Waste disposal and treatment are critical as populations grow and waste accumulates. Municipal wastes, if left untreated and uncontrolled, can cause significant harm to the environment through carbon dioxide emissions, soil and water contamination, and plastic accumulation in oceans and rivers [1]. Waste management is complicated because waste is generated from a variety of sources and has varying degrees of toxicity. Numerous tasks, including sorting and transportation, are involved when all stakeholders are considered [2]. Globally, it is estimated that 2.01 billion tons of municipal waste are generated, with 0.25 billion tons generated in EU member states [3]. While the majority of European countries experience slow population growth, their industries are constantly growing and evolving, generating waste that must be treated. Prevention and treatment are the two primary management strategies. Prevention entails reducing waste entering the waste stream by increasing consumer and producer awareness and changing common unsustainable consumer and producer behaviors [4]. Incineration, landfilling, recycling and composting, and digestion are the four primary methods of municipal waste treatment in the European Union [2,5]. According to a recent study, countries such as Austria, Denmark, and Germany were the most successful in terms of municipal waste treatment policies. Eastern European countries, on the other hand, performed poorly [2,6]. This paper will examine the application of various waste disposal technologies over the last three decades in the European Union (EU), with a focus on specific member countries where necessary. The current state of waste disposal is discussed, followed by a discussion of the various technological solutions available for waste management. The difficulties encountered and other environmental concerns regarding the EU's waste management systems are discussed, followed by a discussion of the future prospects.

\section{Current Status of waste disposal technologies in EU}

The average European inhabitant generated approximately $486 \mathrm{~kg}$ of municipal waste per year in 2017, which can be attributed to the high standard of living [3]. The '2008 Waste Framework Directive' is a collection of national laws that direct countries on how to manage waste effectively [4]. Denmark treated the most municipal waste per capita at approximately $785 \mathrm{~kg}$, while Romania treated the least at $228 \mathrm{~kg}$ per capita [4]. In Northern and Central Europe, the countries that ranked highest for effective municipal waste treatment did so because they phased out traditional landfills and increased their use of incinerators, recycling, and composting. On the other hand, Eastern European countries such as Poland and Slovakia, which continue to rely heavily on landfills for waste treatment, ranked last [4]. Denmark, Germany, Austria, the Netherlands, and Belgium, for example, have almost entirely phased out landfills. By contrast, Cyprus, Malta, Greece, and Croatia continue to rely heavily on landfills for waste disposal. This disparity exists because countries differ in terms of their level of development, consumption patterns, and waste management strategies [4,7]. Additionally, many of these countries joined the EU in the early 2000s, necessitating adaptation to the union's 
new laws and guidelines [4]. Currently, the EU employs four waste treatment methods. Landfills are used to store waste either on or within the ground. Thermal treatment of waste occurs during incineration, biodegradable waste occurs during composting, and wastes are sorted and reprocessed during recycling. Landfills, incinerators, and composting are all wasteto-energy processes, as they generate heat and electricity.

\section{Types of technology in use}

Municipal solid waste is an important resource that can be converted into renewable energy to help meet the world's growing energy demand. Municipal waste is treated using a variety of biochemical, physical, and biological processes that are selected based on factors such as waste composition and climate.

\subsection{Landfills}

Landfills are the most frequently used method of municipal waste treatment in the world. The socioeconomic benefits of landfill use include the generation of electricity and the creation of new jobs. Sanitary landfills contain wastes in cells lined on the bottom to prevent leachate seepage. Leachate is collected and transported to a treatment plant for treatment before it is deemed safe for release into water channels [8]. Waste is frequently buried in soil, compacted, and then covered with another lining to collect methane gas. This gas is then transported to a power plant where it is used to generate electricity [9]. Solar photovoltaic cells (PV) are installed across vast landfills in sunny climates to generate additional electricity [10]. Solar PV has generated some interest in the industry, and its use has increased significantly as the cost of manufacturing materials has decreased and energy demand has increased [11]. Another variation is the bioreactor landfill, in which the environment is controlled to promote organic waste biodegradation. However, the initial and ongoing costs of bioreactor landfills are extremely high, as extensive research is required and the aerobic/anaerobic environment must be regulated via air and moisture injection [12]. Traditional landfills, which bury waste in soil, pose a high risk of contaminating nearby soil and water with harmful pollutants [13]. Increased carbon dioxide and methane emissions contribute to the greenhouse effect. Landfills contribute significantly to air, noise, and odour pollution, which has a negative effect on the economic value of nearby housing [14]. Space has become increasingly scarce, complicating the process of selecting appropriate landfills. However, as a result of European Commission policies, landfills have been closed throughout Europe, and alternative waste management technologies have been promoted [15].

\subsection{Incineration}

Incineration is a type of thermal treatment that involves the controlled combustion of primarily organic wastes. It is regarded as a proper method because it can help reduce waste sent to landfills and incineration plants take up little space [16]. It is a quick solution that immediately reduces waste volume, and the heat generated can even be used to generate electricity, reducing the country's reliance on fossil fuels $[16,17]$. However, there are numerous disadvantages. One of the primary concerns is the generation of pollutants such as heavy metals and dioxins during the incineration of inorganic wastes [18]. Numerous these pollutants are persistent and can travel great distances from their source. Inhalation, ingestion, and contact with contaminated 
media are all routes of exposure that contribute to an increased risk of developing diseases such as cancer and reproductive abnormalities [19,20]. Among them, the literature consistently reported that the primary route of toxic emission exposure is through dietary ingestion [21]. Additionally, incineration has high capital and operating costs, as it requires additional fuel to maintain the combustion process, as well as the installation of critical air pollution control devices and skilled technical personnel to operate the process [16].

\subsection{Recycling}

Recycling is the process of collecting, sorting, and refurbishing materials in order to reuse them rather than dispose of them permanently. Long-life materials, particularly plastic, metals, and glass, can be recycled into raw materials for production. Numerous benefits accrue from maximizing the value of products, resources, and materials while reducing the supply of new materials [22]. Recycling also reduces waste sent to landfills, thereby mitigating landfill-related issues such as leachate contamination and carbon dioxide emissions. Recycling contributes to economic stability by generating new jobs and lowering the costs associated with starting from scratch. However, countries require adequate infrastructure in order to implement waste recycling policies and guidelines [22]. Numerous EU countries continue to rely heavily on landfills, where trash is not separated but rather piled together. In some instances, it can be challenging to separate materials such as food packaging or hygienic waste (diapers, paper tissues, etc.) into recyclable fractions with a market value for a collection system that is not yet established [23]. Additionally, this scenario appears to be technically and economically impossible to implement. Financial incentives, educational awareness, ease of transportation, and private sector participation are all factors that can be implemented to improve developed and developing countries' recycling systems [24].

\subsection{Composting}

Composting is the process by which organic waste, such as food scraps and leaves, is broken down into stable organic and inorganic components. It entails the use of microorganisms in aerobic or anaerobic environments, as well as the manipulation of other variables such as temperature, $\mathrm{pH}$, nutrients, and moisture. It is a form of recycling because it produces biofuels and heat that can be used to generate renewable electricity. There are two primary methods of composting: non-reactor and reactor systems [25]. Windrow, a non-reactor system, involves mechanically mixing waste feedstock in tall reactor tanks [25]. Composting is a sustainable solution because it has the primary benefit of reducing the amount of organic waste disposed of in landfills and incinerators. Biogas is produced as a renewable energy source. Another option is to produce green gas in the form of biomethane, which contains over $95 \%$ methane and has properties similar to natural gas [26]. As a result, it can be applied to other applications in the same way that natural gas is. The process produces liquid fertilizers, which are beneficial for crop production [25]. Europe has benefited from composting food wastes for the last 30 years as landfill space has become scarce [25].

\section{Challenges and Other environmental considerations}

The composition of waste, climate conditions, and management practices all have an effect on the environmental impacts of various waste disposal technologies. For example, the 
greater the proportion of biodegradable waste stored in landfills, the more detrimental the environmental impacts [27]. It is consistent with the EU's prohibition on the disposal of biodegradable waste in landfills. Despite sharing the same policies, socioeconomic factors have segregated the EU's member states' waste management strategies. For example, some countries have eliminated landfills entirely, while others continue to rely on landfills as their primary waste treatment solution. These countries should receive additional assistance to facilitate the implementation of the most advanced disposal technologies and schemes.

While incineration is the most widely used waste disposal method in the EU, it still has negative environmental consequences, such as the release of toxic pollutants [19]. Continuous research and investigation are required to ensure the development and innovation of new technologies that will help mitigate the effects of air pollution. Europe exports a large proportion of recycled plastics, and a recent study estimated that $3 \%$ of these plastics ended up in the ocean in 2017, amounting to an alarming 83,187 tons [28]. Europe exports $46 \%$ of recycled waste to low-cost countries, where it is either reused or disposed of in landfills or through incineration. Plastic is extremely persistent in nature, posing a deadly threat to marine life and accumulating up the food chain. While more definitive data on the origin and path of plastics that end up in the ocean are required, additional evaluation of waste management policies is necessary to ensure the circular economy promoted in the EU succeeds [28].

\section{Future Prospects}

By 2030, the EU intends to recycle 65 percent of municipal waste and keep landfills to a maximum of 10\% [2]. In January 2018, the European Commission published the 2018 Circular Economy Package, which aims to create a circular economy in the EU [29]. It is a novel concept for promoting sustainable development in which production is revolutionized through the recycling, reusing, and refurbishment of wastes. It will assist in maximizing the value of products and extending their shelf life, thereby closing the loop and conserving valuable resources [27,29]. Additionally, the EU seeks to change consumer and producer behaviors toward waste prevention through education, financial incentives, and strict waste generation and management [2]. Waste must be viewed as a resource to be tapped rather than as a nuisance [30]. Cooperation within and between EU member states is a positive step. For example, countries with excess capacity can assist other countries, benefiting all parties, as Sweden and Norway have demonstrated [30]. The member countries' direction and efforts to meet municipal waste management targets must be more unified.

\section{Conclusion}

The primary waste management technologies currently used in the EU to address their increased waste production are landfill, incineration, recycling, and composting. The advantages and disadvantages of these technologies were discussed, and it was noted that wealthier EU member states have gradually phased out landfills in order to promote green development. The objective is to safeguard and conserve natural resources, including the environment, through economic, social, and environmental sustainability. The success of waste management programs is influenced by a variety of factors, including political, economic, environmental, social, technological, and educational. Apart from waste treatment, considerable emphasis is being placed on waste prevention, specifically minimizing waste 
generated at the source. Numerous recent studies provide evidence and leverage for evaluating the efficacy and enhancing the effectiveness of current municipal waste management strategies. EU legislation and schemes should be implemented uniformly across all member countries, including landfill bans, waste disposal taxes, and recycling incentives. In terms of legislation and implementation, assistance should be provided to less prosperous Eastern European countries with fewer resources than the rest of the EU. Concerning the disposal of recycled plastics, more effective solutions must be implemented rather than sending the majority to poorer countries, which is detrimental to the environment.

\section{Acknowledgments}

The authors thank Curtin University Malaysia for facilitating this work. Collaboration from Universiti Malaysia Pahang, Universiti Teknologi Malaysia, University of Yamanashi Japan, University of Science Vietnam, Vietnam National University and National Research and Innovation Agency Indonesia are highly appreciated.

\section{Competing Interest}

The authors declare that they have no known competing financial interests or personal relationships that could have appeared to influence the work reported in this paper.

\section{References}

[1] Bashir, I.; Lone, F.A.; Bhat, R.A.; Mir, S.A.; Dar, Z.A.; Dar, S.A. Concerns and Threats of Contamination on Aquatic Ecosystems. In Bioremediation and Biotechnology: Sustainable Approaches to Pollution Degradation, Hakeem, K.R., Bhat, R.A., Qadri, H., Eds.; Springer International Publishing: Cham, 2020; pp. 1-26.

[2] Castillo-Giménez, J.; Montañés, A.; Picazo-Tadeo, A.J. (2019). Performance and convergence in municipal waste treatment in the European Union. Waste Management, 85, 222-231. https://doi.org/10.1016/j.wasman.2018.12.025.

[3] Ríos, A.-M.; Picazo-Tadeo, A.J. (2021). Measuring environmental performance in the treatment of municipal solid waste: The case of the European Union-28. Ecological Indicators, 123, 107328. https://doi.org/10.1016/j.ecolind.2020.107328.

[4] Castillo-Giménez, J.; Montañés, A.; Picazo-Tadeo, A.J. (2019). Performance in the treatment of municipal waste: Are European Union member states so different? Science of The Total Environment, 687, 1305-1314. https://doi.org/10.1016/j.scitotenv.2019.06.016.

[5] Pomberger, R.; Sarc, R.; Lorber, K.E. (2017). Dynamic visualisation of municipal waste management performance in the EU using Ternary Diagram method. Waste Management, 61, 558571. https://doi.org/10.1016/j.wasman.2017.01.018.

[6] Mazurek, D.; Czapiewski, K. (2021). What Solutions for Waste Management? Issues of Flows and Governance Exemplified by the Łódź Agglomeration (Poland). 14, 3366.

[7] De Laurentiis, V.; Corrado, S.; Sala, S. (2018). Quantifying household waste of fresh fruit and vegetables in the EU. Waste Management, 77, 238-251. https://doi.org/10.1016/j.wasman.2018.04.001.

[8] Madon, I.; Drev, D.; Likar, J. (2019). Long-term risk assessments comparing environmental performance of different types of sanitary landfills. Waste Management, 96, 96-107. https://doi.org/10.1016/j.wasman.2019.07.001.

[9] Bove, R.; Lunghi, P. (2006). Electric power generation from landfill gas using traditional and innovative technologies. Energy Conversion and Management, 47, 1391-1401. https://doi.org/10.1016/j.enconman.2005.08.017.

[10] Ciriminna, R.; Albanese, L.; Pecoraino, M.; Meneguzzo, F.; Pagliaro, M. (2018). Solar Landfills: Economic, Environmental, and Social Benefits. 6, 597-604. https://doi.org/10.1002/ente.201700620. 
[11] Nain, P.; Kumar, A. (2020). Metal dissolution from end-of-life solar photovoltaics in real landfill leachate versus synthetic solutions: One-year study. Waste Management, 114, 351-361. https://doi.org/10.1016/j.wasman.2020.07.004.

[12] Berge, N.D.; Reinhart, D.R.; Batarseh, E.S. (2009). An assessment of bioreactor landfill costs and benefits. Waste Management, 29, 1558-1567. https://doi.org/10.1016/j.wasman.2008.12.010.

[13] Pivato, A.; Gaspari, L. (2006). Acute toxicity test of leachates from traditional and sustainable landfills using luminescent bacteria. Waste Management, 26, 1148-1155. https://doi.org/10.1016/j.wasman.2005.10.008.

[14] Nelson, A.C.; Genereux, J.; Genereux, M. (1992). Price Effects of Landfills on House Values. Land Economics, 68, 359-365. 10.2307/3146693.

[15] Kettunen, M.; Vuorisalo, T. (2005). History and development of Finnish landfill research: impacts of legislative changes and EC policies. Resources, Conservation and Recycling, 44, 51-71. https://doi.org/10.1016/j.resconrec.2004.09.003.

[16] Nanda, S.; Berruti, F. (2021). A technical review of bioenergy and resource recovery from municipal solid waste. Journal of Hazardous Materials, 403, 123970. https://doi.org/10.1016/j.jhazmat.2020.123970.

[17] Sharma, A.; Aloysius, V.; Visvanathan, C. (2019). Recovery of plastics from dumpsites and landfills to prevent marine plastic pollution in Thailand. Waste Disposal \& Sustainable Energy, 1, 237-249. 10.1007/s42768-019-00027-7.

[18] Xue, Y.; Liu, X. (2021). Detoxification, solidification and recycling of municipal solid waste incineration fly ash: A review. Chemical Engineering Journal, 420, 130349. https://doi.org/10.1016/j.cej.2021.130349.

[19] Allsopp, M.; Costner, P.; Johnston, P. (2001). Incineration and human health. Environmental Science and Pollution Research, 8, 141-145. 10.1007/BF02987308.

[20] Li, W.; Achal, V. (2020). Environmental and health impacts due to e-waste disposal in China - A review. Science of The Total Environment, 737, 139745. https://doi.org/10.1016/j.scitotenv.2020.139745.

[21] Tait, P.W.; Brew, J.; Che, A.; Costanzo, A.; Danyluk, A.; Davis, M.; Khalaf, A.; McMahon, K.; Watson, A.; Rowcliff, K.; et al. (2020). The health impacts of waste incineration: a systematic review. 44, 40-48. https://doi.org/10.1111/1753-6405.12939.

[22] Taleb, M.A.; Al Farooque, O. (2021). Towards a circular economy for sustainable development: An application of full cost accounting to municipal waste recyclables. Journal of Cleaner Production, 280, 124047. https://doi.org/10.1016/j.jclepro.2020.124047.

[23] Van Caneghem, J.; Van Acker, K.; De Greef, J.; Wauters, G.; Vandecasteele, C. (2019). Waste-toenergy is compatible and complementary with recycling in the circular economy. Clean Technologies and Environmental Policy, 21, 925-939. 10.1007/s10098-019-01686-0.

[24] Ferronato, N.; Ragazzi, M.; Gorritty Portillo, M.A.; Guisbert Lizarazu, E.G.; Viotti, P.; Torretta, V. (2019). How to improve recycling rate in developing big cities: An integrated approach for assessing municipal solid waste collection and treatment scenarios. Environmental Development, 29, 94-110. https://doi.org/10.1016/j.envdev.2019.01.002.

[25] Silva, M.; Naik, T. Review of composting and anaerobic digestion of municipal solid waste and a methodological proposal for a mid-size city. 2007.

[26] Fernández-González, J.M.; Martín-Pascual, J.; Zamorano, M. (2020). Biomethane injection into natural gas network vs composting and biogas production for electricity in Spain: An analysis of key decision factors. Sustainable Cities and Society, 60, 102242. https://doi.org/10.1016/j.scs.2020.102242.

[27] Sauve, G.; Van Acker, K. (2020). The environmental impacts of municipal solid waste landfills in Europe: A life cycle assessment of proper reference cases to support decision making. Journal of Environmental Management, 261, 110216. https://doi.org/10.1016/j.jenvman.2020.110216.

[28] Bishop, G.; Styles, D.; Lens, P.N.L. (2020). Recycling of European plastic is a pathway for plastic debris in the ocean. Environment International, 142, 105893. https://doi.org/10.1016/j.envint.2020.105893.

[29] EC. European Parliament and Council Directive 2008/98/EC on waste (Waste Framework Directive). European Commission, Brussels. 
[30] Malinauskaite, J.; Jouhara, H.; Czajczyńska, D.; Stanchev, P.; Katsou, E.; Rostkowski, P.; Thorne, R.J.; Colón, J.; Ponsá, S.; Al-Mansour, F.; et al. (2017). Municipal solid waste management and waste-to-energy in the context of a circular economy and energy recycling in Europe. Energy, 141, 2013-2044. https://doi.org/10.1016/j.energy.2017.11.128.

(c) ()

(C) 2021 by the authors. This article is an open access article distributed under the terms and conditions of the Creative Commons Attribution (CC BY) license (http://creativecommons.org/licenses/by/4.0/). 